\title{
AVAILABILITY OF LITERATURE ON ENGINEERING ETHICS IN THE INTERNET
}

\author{
YuSOF ISMAIL AND SUHAIMI MHD SARIF \\ Department of Business Administration, \\ Kulliyyah of Economics and Management Sciences, \\ International Islamic University Malaysia, \\ Jalan Gombak, 53100, Kuala Lumpur, Malaysia. \\ yusof_iiu@yahoo.com; albanjari@yahoo.com
}

\begin{abstract}
Internet is becoming a popular tool among career oriented people. Among professionals, some of the engineers use the Internet in their work to search for information. The study is carried out to ascertain comparative availability of the materials on ethics and engineers in four top Internet search engines (ISE's). Three ISE's were accessed on 2 February 2011, from 2.21 p.m. to 4.21 p.m. [Gombak Time] using a combination of selected search terms: education, engineer, engineering, ethics, Islam, professional, research, and training. The search results or hits produced by the selected ISE's were analyzed using a specially created instrument/format. The study computes relative ratios of the coverage of selected terms in relation to the number of hits for selected terms within each ISE. The ratios are obtained by dividing the hits for a search term or combination into the total hits within each ISE. The results of the analysis reveal the ISE's that contain the highest frequency of materials on engineers and ethics. The findings suggest to engineering students and practitioners of varying capabilities among the ISE's used in the study to learn about engineering ethics. Limitations of the study and suggestions for further research are included in the study.
\end{abstract}

ABSTRAK: Internet menjadi alat yang popular di kalangan staf yang berorientasikan kerjaya. Di kalangan profesional, para jurutera menggunakan Internet untuk mencari maklumat dalam kerja-kerja mereka. Kajian ini dijalankan untuk menentukan ketersediaan perbandingan bahan-bahan mengenai etika dan jurutera dalam empat enjin carian Internet (ISE) teratas. Beberapa ISE dicapai pada 2 Februari 2011, di antara 2.21 petang sehingga 4.21 petang [waktu Gombak] menggunakan gabungan terma carian yang dipilih: pendidikan, jurutera, kejuruteraan, etika, Islam, profesional, penyelidikan, dan latihan. Keputusan carian atau 'hits' yang dihasilkan oleh ISE terpilih telah dianalisis dengan menggunakan instrumen/format yang direka khas. Kajian itu mengira nisbah relatif liputan terma-terma terpilih tersebut dengan jumlah 'hits' bagi kesemua terma bagi setiap ISE. Nisbah diperolehi dengan membahagikan 'hits' bagi istilah carian atau gabungan istilah dengan jumlah 'hits' dalam setiap ISE. Keputusan analisis menunjukkan ISE yang mengandungi kekerapan tertinggi bahan-bahan berkaitan dengan jurutera dan etika. Hasil kajian menyarankan kepada pelajar-pelajar dan pengamal kejuruteraan bahawa wujud keupayaan yang berbeza-beza di kalangan ISE berhubung dengan potensi bahan-bahan berkaitan etika kejuruteraan. Batasan kajian dan cadangan untuk penyelidikan selanjutnya dimasukkan dalam kajian ini.

KEYWORDS: internet search engines; engineer; engineering ethics; training and development 


\section{INTRODUCTION}

Educating engineers with ethics and behavioral science is essential to ensure the sustainability of the development of engineering knowledge [1]. The inclusion of values in engineering requires acceptance from all stakeholders [1]. Engineers must maintain their professionalism at all stages of the profession and aspects of life, including how to solve ethical problems professionally [2]. In today's competitive and globalised world, talent and innovation with ethical dimension is highly valuable [3]. Engineers must be concerned with and learn about ethics in their decision making process so that they can remain ethical and competitively better than their rivals [3]. Ethics is a study on right (acceptable) and wrong (rejected) conduct or manner in the society or organizations [29-30]. A study on ethics is appropriate for any discipline or profession.

This paper examines relative availability of materials related to engineering ethics in order to develop hands-on, professional, ethical and valuable engineers [2][3], which is promoted by the Malaysian Government in its innovative economic, social, political and technology transformation programs [4]. Related terms are also searched for comparative purposes, i.e. based on the premise that rich databases of literature could imply that the concept is progressing rapidly [5].

The main objective of the study is to examine the relative frequency of engineering ethics and related concepts that are available in the Internet search engines. It does not investigate the quality of the contents of the Web-based materials available in the ISE's. One of the results of the study will be able to answer this question: How many hits are produced when the term "engineering" is used in comparison with "ethics," "Islam," "professional," "research," and "training"?

\section{LITERATURE REVIEW}

The literature review section discusses two important points: types of Internet search engines and extent of usefulness of different Internet search engines.

\subsection{Types of Internet Search Engines}

There are many Internet Search Engines (ISEs) that have been used widely in searching for information for the quantity as well as quality [6-7]. For example, Mettrop and Nieuwenhuysen evaluated thirteen Internet search engines, namely AltaVista, EuroFerret, Excite, HotBot, InfoSeek, Lycos, MSN, NorthernLight, Snap, WebCrawler, Ilse, Search.nl, and Vindex [8]. Fluctuations or complications are characteristics of the performance of the Internet search engines [9-10]. The fluctuations in the search results do affect the efficiency of Internet search as a publication/communication medium [9, 11-12].

\subsection{Extent of Usefulness of Different Internet Search Engines}

Dreilinger and Howe found that large data obtained from the ISE's may pose difficulties in the selection process [13]. It is also time consuming to filter them, which eventually may not render the results useful [12-13]. Prior to the preceding study, Tomaiuolo and Packer found that similar results in one ISE also appeared in the other ISEs [14]. The repetition can be used as checker against the accuracy of the information within and among the ISE's [12-13]. Leighton and Srivastana argue that these rich results give more confidence in terms of information accuracy but not so much of effectiveness of information retrieval [15]. 
Wang, Xie and Goh contend that search engines are widely used as tools to find useful information from the Internet [16]. However, most search engines were developed on the basis of technical requirements and without much consideration of the customer's perspective. Ideally, ISE's should be very helpful not only to the designers, but also to the users.

Sullivan identified fourteen Internet Search Engines (ISE's) which he classified as top choices (Google, Yahoo, and Bing), strongly considered (Alltheweb, AOL, HotBot, and Teoma), and other choices (Altavista, Gigablast, LookSmart, Lycos, MSN, Netscape, and Open Directory) [17].

\section{METHODOLOGY}

This section has two parts: objective of the study and method of data collection. While the objective of the study explains the purpose of the study, the method of data collection describes the approaches for collection data for the study.

\subsection{Objective of the Study}

The objective of study is to ascertain the number of hits of the terms related to engineering ethics that were produced by the selected Internet search engines (ISE's). Major search terms used include education, engineer, engineering, ethics, Islam, professional, research, and training. Related terms are included in the search in order to generate comparative data.

The study is carried out to ascertain comparative availability of the materials on ethics and engineers in three top Internet Search Engines (ISE's): Google, Yahoo and Bing, from Sullivan's top choices only [17]. Sullivan's complete list comprised: top choices (Google, Yahoo, and Bing), strongly considered (Alltheweb, AOL, HotBot, and Teoma), and other choices (Altavista, Gigablast, LookSmart, Lycos, MSN, Netscape, and Open Directory) [17].

\subsection{Method}

The Internet was accessed on 2 February 2011, from 2.21 p.m. to 4.21 p.m. [Gombak Time] using a combination of selected search terms: education, engineer, engineering, ethics, Islam, professional, research, and training. A tabular format is created to capture the data of interest for each search engine. The ratio of hits for each term within each ISE is computed by dividing the hits into the total hits for the search engine.

The use of ratios to compute hits produced by the Internet search engines provides a means to assess impacts [18]. Moreover, it is more appropriate to make inference from the use of ratios [19], although such approach can be less reliable statistically [20]. Given time constraints, it is still economical to use ratio approach [19].

There are five stages involved in the process of computing the ratios, namely, (1) identify search engines, (2) record number of hits for specified search terms, (3) compute the ratios, (4) consolidate all the ratios, and (5) perform the analysis.

\section{FINDINGS}

The findings section presents the results in terms of the number of hits of the terms related to engineering ethics that were produced by the Internet search engines (ISE's). The 
terms searched include education, engineer, engineering, ethics, Islam, professional, research, and training.

The results of the study are presented according to the five steps enumerated earlier. Firstly, identify the Internet search engines. The study adopted the list of ISE's identified by Sullivan (2004). However, the study limits itself to three "top choices" of Internet search engines, namely, Google (www.google.com), Yahoo (www.yahoo.com), and Bing (www.bing.com). Secondly, record the number of hits. The researchers recorded the hits shown for all the search terms, i.e., education, engineer, engineering, ethics, Islam, professional, research, and training.

Table 1 shows the hits produced by four ISE's: Google, Yahoo, AlltheWeb and AOL Search. The ISEs show the highest total hits for the terms "Engineer" and its combination with "Ethics," "Ethics Education," "Ethics Islam," "Ethics Professional," "Ethics Research," "Ethics Training," and "Ethics Education Professional Training." Google produced the highest hits $(211,000,000)$ for "Engineer," while Yahoo and AlltheWeb produced the highest hits for "Engineer Ethics $(23,800,000)$," "Engineer Ethics Islam (2,020,000)," "Engineer Ethics Training (8,610,000)," and "Engineer Ethics Education Professional Training $(32,500,000)$." Based on these figures, ethics for engineers is available in the area of education for professional training. In assessing the capability of Internet Search Engines (ISEs), Google scores the highest by capturing 44\% of the total hits as opposed to Yahoo and AllTheWeb with 24\% each respectively. AOL Search shows the lowest score, $8 \%$.

Table 1: Hits for search terms "engineer" and others.

\begin{tabular}{|c|c|c|c|c|}
\hline \multirow[t]{2}{*}{ Search Terms } & \multicolumn{4}{|c|}{ Internet Search Engines } \\
\hline & Google & Yahoo & AllTheWeb & AOL Search \\
\hline Engineer & $211,000,000$ & $59,600,000$ & $59,600,000$ & $34,200,000$ \\
\hline Engineer Ethics & $7,780,000$ & $23,800,000$ & $23,800,000$ & 264,000 \\
\hline Engineer Ethics Education & $16,500,000$ & $10,900,000$ & $10,900,000$ & $7,370,000$ \\
\hline Engineer Ethics Islam & $1,340,000$ & $2,020,000$ & $2,020,000$ & 264,000 \\
\hline Engineer Ethics Professional & $11,500,000$ & $8,100,000$ & $8,100,000$ & $1,680,000$ \\
\hline Engineer Ethics Research & $21,100,000$ & $8,720,000$ & $8,720,000$ & $7,540,000$ \\
\hline Engineer Ethics Training & 784,000 & $8,610,000$ & $8,610,000$ & 725,000 \\
\hline $\begin{array}{l}\text { Engineer Ethics Education } \\
\text { Professional Training }\end{array}$ & $6,840,000$ & $32,500,000$ & $32,500,000$ & 415,000 \\
\hline TOTAL & $276,844,000$ & $154,250,000$ & $154,250,000$ & $52,458,000$ \\
\hline Percentage $(\%)$ & 44 & 24 & 24 & 8 \\
\hline
\end{tabular}

Note: 2 February 2011, 2.21 p.m. - 4.21 p.m. Malaysian Time in Gombak, Kuala Lumpur, Malaysia

Table 2 shows the hits produced by the four ISE's: Google, Yahoo, AlltheWeb and AOL Search. Yahoo and AllTheWeb produced higher hits compared to other ISEs. The highest total hits are observed for the term "Engineering (446,000,000 with Google)," but when "Engineering" is combined with other terms, Yahoo and AllTheWeb produced the highest. For example, "Ethics (41,100,000)," "Ethics Education $(10,600,000)$," "Ethics Islam (2,260,000)," "Ethics Professional (8,500,000)," "Ethics Research (8,500,000)," "Ethics Training (16,000,000)," and "Ethics Education Professional Training $(33,100,000) "$. In terms of Internet Search Engines (ISEs) capability, Google scores the 
IIUM Engineering Journal, Vol. 12, No. 5, 2011: Special Issue on Science and Ethics in Engineering Ismail and Mhd Sarif

highest when it captured $41 \%$ of the total hits as opposed to Yahoo and AllTheWeb with $24 \%$ each respectively. The lowest score $11 \%$ is associated with AOL Search. When compared with Table 2, Google's capability was reduced from $44 \%$ to $41 \%$ whereas AOL Search increased from $8 \%$ to $11 \%$ when the key search terms were changed from "Engineer" to "Engineering."

Table 2: Hits for search terms "engineering" and others.

\begin{tabular}{|l|l|l|l|l|}
\hline \multirow{2}{*}{ Search Terms } & \multicolumn{4}{|c|}{ Internet Search Engines } \\
\cline { 2 - 5 } & \multicolumn{1}{|c|}{ Google } & \multicolumn{1}{|c|}{ Yahoo } & \multicolumn{1}{c|}{ AllTheWeb } & AOL Search \\
\hline Engineering & $446,000,000$ & $178,000,000$ & $183,000,000$ & $104,000,000$ \\
\hline Engineering Ethics & $4,050,000$ & $20,200,000$ & $19,600,000$ & $3,900,000$ \\
\hline $\begin{array}{l}\text { Engineering Ethics } \\
\text { Education }\end{array}$ & $7,160,000$ & $10,600,000$ & $10,600,000$ & $7,100,000$ \\
\hline Engineering Ethics Islam & 269,000 & $2,260,000$ & $2,260,000$ & 264,000 \\
\hline $\begin{array}{l}\text { Engineering Ethics } \\
\text { Professional }\end{array}$ & 643,000 & $8,470,000$ & $8,470,000$ & 606,000 \\
\hline $\begin{array}{l}\text { Engineering Ethics } \\
\text { Research }\end{array}$ & $7,370,000$ & $8,500,000$ & $8,500,000$ & $7,350,000$ \\
\hline Engineering Ethics Training & 492,000 & $16,000,000$ & $16,000,000$ & 475,000 \\
\hline $\begin{array}{l}\text { Engineering Ethics } \\
\text { Education Professional } \\
\text { Training }\end{array}$ & 333,000 & $33,100,000$ & $33,100,000$ & 303,000 \\
\hline Ethics & $79,300,000$ & $41,100,000$ & $41,100,000$ & $26,100,000$ \\
\hline TOTAL & $\mathbf{5 4 5 , 6 1 7 , 0 0 0}$ & $\mathbf{3 1 8 , 2 3 0 , 0 0 0}$ & $\mathbf{3 2 2 , 6 3 0 , 0 0 0}$ & $\mathbf{1 5 0 , 0 9 8 , 0 0 0}$ \\
\hline Percentage (\%) & $\mathbf{4 1}$ & $\mathbf{2 4}$ & $\mathbf{2 4}$ & $\mathbf{1 1}$ \\
\hline
\end{tabular}

Note: 2 February 2011, 2.21 p.m. - 4.21 p.m. Malaysian Time in Gombak, Kuala Lumpur, Malaysia.

Table 3 shows the top 10 total hits for "Engineering" and "Engineer" combined with several key terms generated by four ISE's: Google, Yahoo, AlltheWeb and AOL Search. The highest rank is "Engineering" (46\%), followed by "Engineer" (18\%), "Ethics" (9\%), and "Engineer Ethics Education" (4\%). The remaining is not significant as the score is below $4 \%$.

Table 3: Top 10 of total hits for search terms "engineer," "engineering" and other terms.

\begin{tabular}{|l|r|c|}
\hline Search Terms & Total Hits & Rank \\
\hline Engineering & $911,000,000(46 \%)$ & 1 \\
\hline Engineer & $364,400,000(18 \%)$ & 2 \\
\hline Ethics & $187,600,000(9 \%)$ & 3 \\
\hline Engineer Ethics Education Professional Training & $72,255,000(4 \%)$ & 4 \\
\hline Engineering Ethics Education Professional Training & $66,836,000(3.4 \%)$ & 5 \\
\hline Engineer Ethics & $55,644,000(2.8 \%)$ & 6 \\
\hline Engineering Ethics & $47,750,000(2.4 \%)$ & 7 \\
\hline Engineer Ethics Research & $46,080,000(2.34 \%)$ & 8 \\
\hline Engineer Ethics Education & $45,670,000(2.3 \%)$ & 9 \\
\hline Engineering Ethics Education & $35,460,000(1.8 \%)$ & 10 \\
\hline
\end{tabular}


Thirdly, compute the ratios. The ratio for specific term in each search engine is computed by dividing the hits of each search term by total hits for the search engine. The higher the ratio the higher the relative coverage of the search terms in the search engine concerned.

Table 4 produces comparative hits and ratios across the ISE's. The highest ratios were shown for the single term "Engineer" with 0.762 (Google), 0.386 (Yahoo and AllTheWeb/ATW), and 0.652 (AOL Search). When "Engineer" was combined other terms, the ratios reduced significantly, the lowest ratios registered 0.005 for "Engineer Ethics Islam." Likewise, lower ratios were shown for "Engineer Ethics," "Engineer Ethics Education," and the rest.

Table 5 shows comparative hits and ratios across the ISE's. The highest ratios were possessed by the single term "Engineering" with 0.817 (Google), 0.559 (Yahoo and AllTheWeb/ATW), and 0.693 (AOL Search). When "Engineering" was combined with other terms, the ratios reduced significantly, the lowest ratio was 0.000 for "Engineering Ethics Islam." Likewise, other ratios also showed numbers, for example "Engineering Ethics," "Engineering Ethics Education," and the rest.

Table 4: Ratios for search terms "engineer" and other terms.

\begin{tabular}{|c|c|c|c|c|c|c|}
\hline ISEs & Google & & Yahoo ATW & & AOL Search & \\
\hline Terms & Hits & Ratio & Hits & Ratio & Hits & Ratio \\
\hline Engineer & $211,000,000$ & 0.762 & $59,600,000$ & 0.386 & $34,200,000$ & 0.652 \\
\hline Engineer Ethics & $7,780,000$ & 0.028 & $23,800,000$ & 0.154 & 264,000 & 0.005 \\
\hline Engineer Ethics Education & $16,500,000$ & 0.06 & $10,900,000$ & 0.071 & $7,370,000$ & 0.141 \\
\hline Engineer Ethics Islam & $1,340,000$ & 0.005 & $2,020,000$ & 0.013 & 264,000 & 0.005 \\
\hline Engineer Ethics Professional & $11,500,000$ & 0.042 & $8,100,000$ & 0.053 & $1,680,000$ & 0.032 \\
\hline Engineer Ethics Research & $21,100,000$ & 0.076 & $8,720,000$ & 0.057 & $7,540,000$ & 0.144 \\
\hline Engineer Ethics Training & 784,000 & 0.003 & $8,610,000$ & 0.056 & 725,000 & 0.014 \\
\hline $\begin{array}{l}\text { Engineer Ethics Education } \\
\text { Professional Training }\end{array}$ & $6,840,000$ & 0.025 & $32,500,000$ & 0.211 & 415,000 & 0.008 \\
\hline
\end{tabular}

Table 5: Ratios for search terms "engineering" and other terms.

\begin{tabular}{|l|r|r|r|r|r|r|}
\hline ISEs & \multicolumn{2}{l|}{ Google } & \multicolumn{2}{l|}{ Yahoo ATW } & \multicolumn{2}{l|}{ AOL Search } \\
\hline Terms & \multicolumn{1}{l|}{ Hits } & \multicolumn{1}{l|}{ Ratio } & \multicolumn{1}{l|}{ Hits } & \multicolumn{1}{l|}{ Ratio } & \multicolumn{1}{l|}{ Hits } & Ratio \\
\hline Engineering & $446,000,000$ & 0.817 & $178,000,000$ & 0.559 & $104,000,000$ & 0.693 \\
\hline Engineering Ethics & $4,050,000$ & 0.007 & $20,200,000$ & 0.063 & $3,900,000$ & 0.026 \\
\hline Engineering Ethics Education & $7,160,000$ & 0.013 & $10,600,000$ & 0.033 & $7,100,000$ & 0.047 \\
\hline Engineering Ethics Islam & 269,000 & 0.000 & $2,260,000$ & 0.007 & 264,000 & 0.002 \\
\hline Engineering Ethics Professional & 643,000 & 0.001 & $8,470,000$ & 0.027 & 606,000 & 0.004 \\
\hline Engineering Ethics Research & $7,370,000$ & 0.014 & $8,500,000$ & 0.027 & $7,350,000$ & 0.049 \\
\hline Engineering Ethics Training & 492,000 & 0.001 & $16,000,000$ & 0.050 & 475,000 & 0.003 \\
\hline $\begin{array}{l}\text { Engineering Ethics Education } \\
\text { Professional Training }\end{array}$ & 333,000 & 0.001 & $33,100,000$ & 0.104 & 303,000 & 0.002 \\
\hline
\end{tabular}


IIUM Engineering Journal, Vol. 12, No. 5, 2011: Special Issue on Science and Ethics in Engineering

Ismail and Mhd Sarif

\begin{tabular}{|l|l|l|l|l|l|l|}
\hline Ethics & $79,300,000$ & 0.145 & $41,100,000$ & 0.129 & $26,100,000$ & 0.174 \\
\hline
\end{tabular}

Fourthly, consolidate all the ratios. All of the ratios are aggregated into Table 6 to facilitate comparison. The comparative analysis of single search terms "Engineering" and "Engineer" shows that "Engineering" scores the lowest 0.559, whereas "Engineer" 0.386 at Yahoo and AllTheWeb (ATW). When "Engineering" was combined other terms, the lowest ratios produced were 0.000 ("Engineering Ethics Islam" at Google) and 0.001 ("Engineering Ethics Professional," "Engineering Ethics Training," and "Engineering Ethics Education Professional Training" at Google).

Table 6: Consolidated ratios for search terms "engineering," "engineer," and other terms.

\begin{tabular}{|l|r|r|r|}
\hline \multicolumn{1}{|c|}{ Search Terms } & Google & \multicolumn{1}{|c|}{$\begin{array}{c}\text { Yahoo \& } \\
\text { ATW }\end{array}$} & $\begin{array}{c}\text { AOL } \\
\text { Search }\end{array}$ \\
\hline Engineering & 0.817 & 0.559 & 0.693 \\
\hline Engineering Ethics & 0.007 & 0.063 & 0.026 \\
\hline Engineering Ethics Education & 0.013 & 0.033 & 0.047 \\
\hline Engineering Ethics Islam & 0.000 & 0.007 & 0.002 \\
\hline Engineering Ethics Professional & 0.001 & 0.027 & 0.004 \\
\hline Engineering Ethics Research & 0.014 & 0.027 & 0.049 \\
\hline Engineering Ethics Training & 0.001 & 0.050 & 0.003 \\
\hline Engineering Ethics Education Professional Training & 0.001 & 0.104 & 0.002 \\
\hline Ethics & 0.145 & 0.129 & 0.174 \\
\hline Engineer & 0.762 & 0.386 & 0.652 \\
\hline Engineer Ethics & 0.028 & 0.154 & 0.005 \\
\hline Engineer Ethics Education & 0.060 & 0.071 & 0.141 \\
\hline Engineer Ethics Islam & 0.005 & 0.013 & 0.005 \\
\hline Engineer Ethics Professional & 0.042 & 0.053 & 0.032 \\
\hline Engineer Ethics Research & 0.076 & 0.057 & 0.144 \\
\hline Engineer Ethics Training & 0.003 & 0.056 & 0.014 \\
\hline Engineer Ethics Education Professional Training & 0.025 & 0.211 & 0.008 \\
\hline
\end{tabular}

Finally, perform the analysis. The last stage of the analysis identified the highest ratios for single search terms generated by each of the search engines. Table 7 shows that all the four ISE's could capture the specified search terms despite their producing varying ratios. The most eminent term was "Engineering", which appeared as among the highest hits across all four ISEs. Predictably, search terms under Google produced more ratios as opposed to the other ISEs. Clearly, Google is able to produce higher ratios (or hits) compared to other ISEs.

Total hits and ratios will not be that meaningful if one desires to know the productivity of each ISE for specific search terms. Reviewing the ratios from various tables and consolidating them in Tab. VI gives us the notion of efficiency of each search engine for single and combined search terms. Tab. VII shows that Google produced the highest hits (0.817) for generic "Engineering." However, if a person wishes to identify the association between "Engineering" or "Engineer" and "Ethics Islam", Yahoo and AllTheWeb are the 
IIUM Engineering Journal, Vol. 12, No. 5, 2011: Special Issue on Science and Ethics in Engineering

Ismail and Mhd Sarif

more efficient ISEs. Yahoo is rated with 0.013, whereas Google, 0.001 and AOL Search, 0.002 .

Google stands out among the four ISE's for both single and combined search terms. For single search terms, Google's hits produced the highest among eighteen search terms used in this study. Google's hits for single and combined search terms portray a close association with its ratios. This suggests that it is highly probable that Google's materials for combined hits, which are more specific, are included in the generic and single search terms hits.

Table 7: Consolidated ratios for search terms "engineering," "engineer," and other terms under Google, under Yahoo \& ATW, and under AOL Search.

\begin{tabular}{|c|c|c|c|c|c|}
\hline Under Google & Ratios & Under Yahoo \& ATW & Ratios & $\begin{array}{l}\text { Under AOL } \\
\text { Search }\end{array}$ & Ratios \\
\hline Engineering & 0.817 & Engineering & 0.559 & Engineering & 0.693 \\
\hline Engineer & 0.762 & Engineer & 0.386 & Engineer & 0.652 \\
\hline Ethics & 0.145 & $\begin{array}{l}\text { Engineer Ethics } \\
\text { Education Professional } \\
\text { Training }\end{array}$ & 0.211 & Ethics & 0.174 \\
\hline Ethics & 0.145 & Engineer Ethics & 0.154 & Ethics & 0.174 \\
\hline Engineer Ethics Research & 0.076 & Ethics & 0.129 & $\begin{array}{l}\text { Engineer Ethics } \\
\text { Research }\end{array}$ & 0.144 \\
\hline Engineer Ethics Education & 0.060 & Ethics & 0.129 & $\begin{array}{l}\text { Engineer Ethics } \\
\text { Education }\end{array}$ & 0.141 \\
\hline $\begin{array}{l}\text { Engineer Ethics } \\
\text { Professional }\end{array}$ & 0.042 & $\begin{array}{l}\text { Engineering Ethics } \\
\text { Education Professional } \\
\text { Training }\end{array}$ & 0.104 & $\begin{array}{l}\text { Engineering Ethics } \\
\text { Research }\end{array}$ & 0.049 \\
\hline Engineer Ethics & 0.028 & $\begin{array}{l}\text { Engineer Ethics } \\
\text { Education }\end{array}$ & 0.071 & $\begin{array}{l}\text { Engineering Ethics } \\
\text { Education }\end{array}$ & 0.047 \\
\hline $\begin{array}{l}\text { Engineer Ethics Education } \\
\text { Professional Training }\end{array}$ & 0.025 & Engineering Ethics & 0.063 & $\begin{array}{l}\text { Engineer Ethics } \\
\text { Professional }\end{array}$ & 0.032 \\
\hline $\begin{array}{l}\text { Engineering Ethics } \\
\text { Research }\end{array}$ & 0.014 & $\begin{array}{l}\text { Engineer Ethics } \\
\text { Research }\end{array}$ & 0.057 & Engineering Ethics & 0.026 \\
\hline $\begin{array}{l}\text { Engineering Ethics } \\
\text { Education }\end{array}$ & 0.013 & Engineer Ethics Training & 0.056 & $\begin{array}{l}\text { Engineer Ethics } \\
\text { Training }\end{array}$ & 0.014 \\
\hline Engineering Ethics & 0.007 & $\begin{array}{l}\text { Engineer Ethics } \\
\text { Professional }\end{array}$ & 0.053 & $\begin{array}{l}\text { Engineer Ethics } \\
\text { Education } \\
\text { Professional } \\
\text { Training } \\
\end{array}$ & 0.008 \\
\hline Engineer Ethics Islam & 0.005 & $\begin{array}{l}\text { Engineering Ethics } \\
\text { Training }\end{array}$ & 0.050 & Engineer Ethics & 0.005 \\
\hline Engineer Ethics Training & 0.003 & $\begin{array}{l}\text { Engineering Ethics } \\
\text { Education }\end{array}$ & 0.033 & $\begin{array}{l}\text { Engineer Ethics } \\
\text { Islam }\end{array}$ & 0.005 \\
\hline $\begin{array}{l}\text { Engineering Ethics } \\
\text { Professional }\end{array}$ & 0.001 & $\begin{array}{l}\text { Engineering Ethics } \\
\text { Research }\end{array}$ & 0.027 & $\begin{array}{l}\text { Engineering Ethics } \\
\text { Professional }\end{array}$ & 0.004 \\
\hline $\begin{array}{l}\text { Engineering Ethics } \\
\text { Training }\end{array}$ & 0.001 & $\begin{array}{l}\text { Engineering Ethics } \\
\text { Professional }\end{array}$ & 0.027 & $\begin{array}{l}\text { Engineering Ethics } \\
\text { Training }\end{array}$ & 0.003 \\
\hline
\end{tabular}


IIUM Engineering Journal, Vol. 12, No. 5, 2011: Special Issue on Science and Ethics in Engineering

Ismail and Mhd Sarif

\begin{tabular}{|l|l|l|l|l|l|}
\hline $\begin{array}{l}\text { Engineering Ethics } \\
\text { Education Professional } \\
\text { Training }\end{array}$ & 0.001 & Engineer Ethics Islam & 0.013 & $\begin{array}{l}\text { Engineering Ethics } \\
\text { Education } \\
\text { Professional } \\
\text { Training }\end{array}$ & 0.002 \\
\hline Engineering Ethics Islam & 0.000 & Engineering Ethics Islam & 0.007 & $\begin{array}{l}\text { Engineering Ethics } \\
\text { Islam }\end{array}$ & 0.002 \\
\hline
\end{tabular}

\section{DISCUSSION}

Google stands out among the four ISE's for both single and combined search terms. The search terms used include education, engineer, engineering, ethics, Islam, professional, research, and training. For the 18 search terms, Google's hits produced the highest. Google's hits for single and combined search terms reflected its highest ratios. This suggests that it is highly probable that Google's materials for combined hits, which are more specific, are also included in the generic and single search terms hits.

Some key literature of engineering ethics emphasizes on the obligations of employers, society and industry and potential challenges to implement ethics in engineering or to train engineers to be ethical. The scarcity of materials on engineering ethics may hinder employers, society, industry and engineers from reading and researching into engineering ethics. According to Frantz, employers have an obligation to give training on ethics for engineers [21]. When such materials are not readily available in the Internet, the employers might take the matter lightly. Brenkert contends that, for any industries that need innovation, such as engineering and science, some rules and ethics are essential as precautionary measures [22]. Otherwise, such ventures will be less useful for the industry and the users.

Johnson upholds similar argument that ethics plays an essential role in science and engineering [23]. For any society, ethics is catalyst for any right and effective accomplishment [24]. Engineering students need to study ethics because with this knowledge they can identify and evaluate their engineering decisions to be professionally right and ethical [24-25]. Bowden argues that teaching ethics to engineers strengthens their profession for the sake of the society and the industry [26]. According to Coeckelberg, engineering can learn from ethics, and vice versa [27]. Yearley calls for reviews of the societal and ethical aspects of synthetic biology [28].

\subsection{Limitations of the Study}

The study attempted to assess the availability of materials on education, engineer, engineering, ethics, Islam, professional, research, and training. The relative ratios were comparable among the search engines to afford analysis. Ratios are expected to reflect more statistically meaningful indices. Despite this, cross comparisons among ISE do not accommodate adjustments to size (or frequency of hits).

Another limitation of the study is its use of cross-sectional data (hits) at a point in time. Stretching the study over time, for example quarterly, over a few years should be able to provide a meaningful pattern of coverage of the search terms across search engines.

Next, a pilot study with four ISE's, i.e. Google, Yahoo, AllTheWeb and AOL Search, may not be considered adequate compared to the availability of many other search engines. Future study should include the other ISE's as well. 


\subsection{Significance of the Study}

The study is very significant for theoretical development of engineering ethics, public and business policy for engineering ethics, and the general public. The Internet search engine provides instant information on engineering ethics that can be pursued further.

For the public and business policy, engineering ethics contributes to the progress of human beings and economic prosperity. The availability of hits promotes visibility of engineering and its professionalism.

\section{CONCLUSION}

Based on the results of the specific search terms generated from the four ISE's, we can say that the amount of materials on engineering ethics is scarce. Researchers will have to resort to other sources of information to learn about engineering ethics. Despite this limitation, one can still opt to use Google to gather materials on "Engineering" and "Engineer" but if he desires to learn only "Engineering" or "Engineer" who emphasizes "Ethics" then Yahoo is an appropriate search engine. Internet users need to be cautioned that the hits only suggest apparent availability of the materials with the ISE's; they in no way suggest the adequacy and quality of the contents of the materials.

\section{REFERENCES}

[1] K. Mulder, J. Segalas-Coral, D. Ferrer-Balas, "Educating engineers for/in sustainable development? What we knew, what we learned, and what we should learn." Thermal Science, vol. 14, pp.625-639, Sept ember 2010.

[2] P. Bowden, "Teaching ethics to engineers - a research-based perspective." Euro. J. Eng. Edu, vol. 35, pp. 563-572, October 2010.

[3] T.Guo and J. Liu, "Multi-disciplinary education for product design and development." Adv. Mat. Research, vol. 156-157, pp. 681-684, October 2010.

[4] G. Malaysia. Tenth Malaysia Plan (2011-2015). Kuala Lumpur: Malaysia Printing, January 2011.

[5] G. Jim, J. Gao and Y. Wang, " A multi-agent based knowledge search framework to support the product development process." Int J. Comp. Interg. Mfg, vol. 23, pp. 237-247, October 2010.

[6] M. Chau, C.H. Wong, Y. Zhou, and H. Chen, "Evaluating the use of search engine development tools in IT education," J. Ame. Soc. Info. Sci. Tech., vol. 61, pp. 288-299, 2010.

[7] Z. Xiang and U. Gretzel, " Role of social media in online travel information search," Tourism Mgt., vol. 31, pp. 179-188, 2010.

[8] W. Mettrop and P. Nieuwenhuysen, "Internet search engines - fluctuations in document accessibility," J. Doc., vol. 57, pp. 623-651, 2001.

[9] M. Thelwall, "Quantitative comparisons of search engin results," J. Ame. Soc. Info. Sci. Tech., vol. 59, pp. 1702-1710, 2008.

[10] A. Uyar, "Investigation of the accuracy of search engine hit couts," J. Info. Sci., vol. 35, pp. 469-480, 2009.

[11] A. Pirkola, "The effectiveness of web search engines to index new sites from different countries," Info. Res., vol. 14, pp.1-11, 2009.

[12] R. Prabowo and M. Thelwall, " Sentiment analysis: a combined approach," J. Infometric, vol. 3, pp. 143-157, 2009.

[13] D. Dreilinger and A. Howe, "Experiences with selecting search engines using metasearch," ACM Transac. Info. Sys., vol. 15, pp. 195-222, 1997. 
[14] N. Tomaiuolo and J. Parker, " An analysis of internet search engines: assessment of over 200 search queries," Comp.Lib., vol. 16, pp. 58-62, 1996.

[15] H. Leighton and J. Srivastava, "Precision among www search services (search engines): alta vista, excite, hotbot, infoseek and lycos," retrieved from http://www.winona.edu/library/webind2.htm, 21 October 2010.

[16] H. Wang, M. Xie and T. Goh, " Service quality of internet search engines," J. Info. Sci., vol. 25, pp.499-507, 1999.

[17] D. Sullivan, “ Major search engines and directories," retrieved from http://searchenginewatch.com/author/index.php/dannysullivan, 21 October 2010.

[18] K. Bharat and A. Broder, "A technique for measuring the relative size and overlap of public web search engines," $7^{\text {th }}$ Intl. World Wide Web Conf., April 1998.

[19] S. Lawrence and C. Giles, "Searching the world wide web," Science, pp. 98-100, April 1998.

[20] H. Chu and M. Rosenthal, " Search engines for the world wide web: a comparative study and evaluation methodology," ASIS, retrieved from http://www.asis.org/annual96/electronic-proceedings/chu.htm, Retrieved 21 October 2010.

[21] L. Frantz, "Engineering ethics: the responsibility of the manager," Eng. Mgt. Intl., vol. 4, pp. 267-272, January 1988.

[22] G. Brenkert, "Innovation, rule breaking and the ethics of entrepreneurship," J.Bus.Vent., vol. 24, pp. 448-464, September 2009.

[23] D.Johnson, "The role of ethics in science and engineering," Trends Biotech., vol. 28, pp. 589-590, December 2010.

[24] W.Wulf, "Engineering ethics and society," Technology in Soc., vol. 26, pp.385-390, AprilAugust 2004.

[25] V.Weil, "The rise of engineering ethics," Tech. in Soc., vol. 6, 341-345, April 1984.

[26] P. Bowden, "Teaching ethics to engineers - a research-based perspective," Euro. J. Eng. Edu., vol. 35, pp. 563-572, October 2010.

[27] M. Coeckelbergh, "Engineering good: How engineering metaphors help us to understand the moral life and change society," Sci. and Eng. Ethics, vol. 16, pp. 371-385, April 2010.

[28] S. Yearley, "The ethical landscape: Identifying the right way to think about the ethical and societal aspects of synthetic biology research and products," J. Royal Soc. Interface, vol. 6, pp. S559-S564, May 2009.

[29] A. Ghillyer. Business Ethics: A Real World Approach (2nd ed.). New York: McGraw-Hill, 2010.

[30] L. Hartman and J. DesJardins, J. (2011) (2nd edition). Business ethics: Decision-making for personal integrity \& social responsibility. New York: McGraw-Hill/Irwin, 2011 